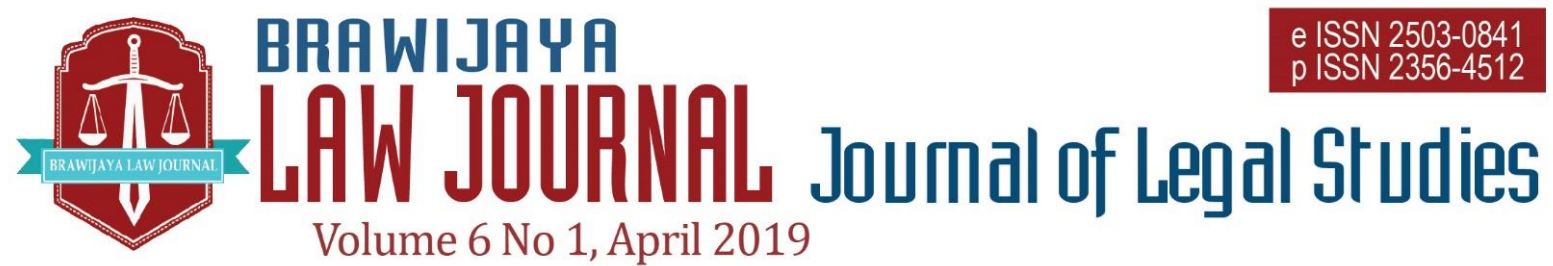

Nationally Accredited No. 30/E/KPT/2018 Dated 24th October 2018

This work is licensed under a Creative Commons Attribution-NonCommercial 4.0 International License

\title{
Legal Status of Cryptocurrency in Indonesia and Legal Analysis of the Business Activities in Terms of Cryptocurrency
}

\author{
Soonpeel Edgar Chang ${ }^{a}$ \\ ${ }^{a}$ Attorney at New York Bar, Korindo Group. Bachelor of Law (LL.B) from Sungkyunkwan \\ University, Master of Law (LL.M) from New York University and National University of \\ Singapore, and Master of Accounting and Finance (Macc.) from Sogang University. \\ Email : soonpeel.chang@gmail.com
}

Submitted : 2018-11-15 | Accepted : 2019-02-08

\begin{abstract}
Indonesia's recent development in legal policy toward cryptocurrency is pertinent to ask whether this new investment market has any more risk to throw over Indonesia than how to protect the existing variable parties by overall structural formation. This tendency has prevented the government to implement the machinery of more fundamental keynote of policy. Against this backdrops, this research first analyzes the existing laws and regulations to examine the current legal status of virtual currency in Indonesia with the method of conceptual analysis. Despite the Government's skeptical stance about economic soundness that cryptocurrency market leads, however, how to protect the various parties in the existing market is a different issue which still needs an urgent attention from policy makers, legal practitioners, judiciary and academic researchers. Therefore, this paper further studies the relevant laws and regulations governing the actual operation of cryptocurrency exchange in Indonesia to discuss the more practical aspects by interviewing an Indonesian cryptocurrency exchange and professional lawyers at Dentons HPRP. Subsequently, the most worrisome legal risks in the industry are diagnosed by interviewing a global cryptocurrency exchanges. This study concludes that BAPPEBTI Regulation No. 5 of 2019 cannot be the good answer to minimize the risk and will only harm bona fide market participants without a good-standing authority.
\end{abstract}

Keywords: virtual currency; cryptocurrency; digital currency; bitcoin; fintech.

\section{INTRODUCTION}

On 8 February 2019, the Indonesian

Future Trading Regulatory Agency ("Bappebti") under the Ministry of Trade issued BAPPEBTI Regulation No.5 of 2019 to directly govern the cryptocurrency ecology whereby Indonesia finally joined the global trends to set the national legal landscape with direct regulations and enforcement ordinances. It was roughly eleven years after the creator of the first cryptocurrency over the world who used a pseudonym of Satoshi Nakamoto defined it 
as "a chain of digital signatures" in 2008. ${ }^{1}$ and around two years after the Indonesian central bank ("Bank Indonesia") named it "virtual currency" and defined it as "digital money issued by a party other than the monetary authority obtained by way of mining, purchase or transfer of reward and includes Bitcoin, Blackoin, Dash Dogecoin, Litecoin, Nxt, Peercoin, Primecoin, Ripple, and Ven." (Official Elucidation of each of Art. 34 Item. (a) of BI Reg. 18/69/ PBi/2016 and Article 8 of BI Reg.19/12/PBI/2017).

This definition is not only deviated from the accepted definition in other jurisdictions, ${ }^{2}$ but also clearly misleading. For instance, notwithstanding its definition as digital "money", it is not legally recognized as a valid payment instrument in Indonesia (Article 8 of BI Reg.19/12/PBI/2017). Nor is it recognized as a legal currency despite its name of virtual "currency" because Rupiah is the only national currency in Indonesia (BI Reg. No.7/2011). In other words, the term "digital money" or "virtual currency" does not help to grasp what it is.

However, the biggest problem laying in virtual currencies' ecosystem in Indonesia is not the misleading definition, but a lack of clear keynote in national policy regarding how to specifically regulate the

\footnotetext{
1 "We define an electronic coin as a chain of digital signatures." See Satoshi Nakamoto, Bitcoin: A Peer-to-Peer Electronic Cash System, (2008) <www.bitcoin.org > 2.

2 For instance, New York Codes, Rules and Regulations, Title 23 sec. 200.4 200.20; Regulation of the Conduct of Virtual Currency Businesses, 37 N.Y. Reg. June 24, 2015, Art. 200.2(p); Financial Crimes Enforcement Network, Application of Fin CEN's Regulations to Persons Administering, Exchanging or Using Virtual Currencies (18 March 2013) FIN-2013-G001; FATF, Virtual Currencies - Key Definitions and Potential AML/ CFT Risks (2014) 6 Financial Action Task Force Report, 4.
}

cryptocurrency market and legally protect the variable parties.

A series of Indonesian policies toward cryptocurrency so far seem to be skeptical whether the cryptocurrencies' ecosystem can contribute to national financial stability and sound economic growth. First, the BI Regulation Number 19/12/PBI/2017 prohibiting fintech firms from processing payment transactions that use virtual currency strike hard at the entire virtual currencies' ecosystem in Indonesia. Following this ban, Indonesian bitcoin payment platforms including Toko Bitcoin and Bitbayar have closed down voluntarily in October 2017 and other surviving virtual currency exchanges such as ArtaBit, Luno and Indodax was gripped by desperation with the concerns over the government taking a more aggressive move to wipe out the entire virtual currencies' industry in Indonesia. ${ }^{3}$

Second, when the market price of Bitcoin reached its peak from December 2017 to January 2018, the Government's concerns also reached a new high. Each of Bank Indonesia, the Indonesian Ministry of Finance, and the Indonesian Financial Transaction Reports and Analysis Center (Pusat Pelaporan dan Analisis Transaksi Keuangan or PPATK) issued a press lease to warn the public against the use or investment to virtual currency. ${ }^{4}$ At the same time, the

3 See Sri Rahayu and Indriana Pramestri, Fintech 2018 Indonesia (21 May 2018) International Comparative Legal Guides, $<$ https://iclg.com/practice-areas/fintech-laws-andregulations/indonesia> assessed on 10 August 2018.

4 Communication Department of Bank Indonesia, Bank Indonesia Warns All Parties Not to Sell, Buy, or Trade Virtual Currency, 13 January 2018; Indonesian Ministry of Finance, Warning Against the Use of Virtual Currency in Indonesia, 22 January 2018, and ; PPATK, Beware of the Use of Virtual Currency, 12 February 2018. These reports note in common that (i) virtual currency is not a currency; (ii) the exchange rate of a virtual currency can easily fluctuate and therefore 
Financial Supervisory Services Authority (OJK) and Bank Indonesia officially urged the public to refrain from owning, acquiring or trading cryptocurrency following a prelaunch event of cryptocurrency-based investment products by Aladin Capital, a global financial group based in the Unites States and Switzerland. ${ }^{5}$

As the price of Bitcoin has significantly withered since then, there has been no particular attempt from the Government to adopt any regulation in order to govern activities with virtual currencies as a part of fintech industry until Bappebti announced its sign on a decree to allow cryptocurrency trading on futures exchanges as a commodity. Soon after, the Ministry of Trade permitted the Crypto Asset Future Trading by adopting the regulation No.99 of 2018. Albeit the Investment Watch Task Force under OJK supervises and monitors suspicious activities including the field of cryptocurrency, ${ }^{6}$ a broad range of legal application among the different parties in the market (e.g., investor, owner, seller, purchaser, developer, exchange business holder, secured creditor, various parties in initial public offering, or any interest holder) has remained significantly ambiguous. Not surprisingly, during this period of time, the lack of any exploration taken by the judiciary, academic explications, or theoretical developments in the field with its own originality and rigors worsened the situation.

Finally, Bappebti announced the Regulation No. 5 of 2019, which virtually prohibit all the existing cryptocurrency exchanges by requiring astronomical amount

vulnerable to bubble risks; (iii) there is no authority in responsible for virtual currencies and there is no official administrator; (iv) there is no underlying asset that serves as a basis for the value; and (v) there is a lack of consumer protection. to do business. This regulation raised both theoretical and practical problems. From a theoretical perspective, this measure seems inherently unlawful per se because cryptocurrency itself is not a future commodity but merely a commodity which can be merely a subject matter of future trading (Article 1 of the Ministry of Trade Regulation No.99/2018). This theoretical flaw over the authority of the issuing body may render the regulation unconstitutional due to the violation of Article 17 Paragraph (3) and Article 18A (1) of Indonesian Constitution of Constitution. (A detailed explanation is discussed later.) Indeed, this approach to govern the business of virtual currency exchange as futures trading business in a whole is far from the global trends in regulating the same market.

In other words, at this juncture in its development, Indonesia does not accommodate the tenets of global policies in the fundamental lever, but merely sticks to making piecemeal regulations while evading rigorous work to successfully bring out a clear regulation from this challenging subject. Even though the Government's skeptical stance about soundness of the cryptocurrency markets is fully understandable, how to protect the various parties in the existing market is a different issue which needs an urgent attention from policy makers, legal practitioners, judiciary and academic researchers. It must be studied at least how the existing statutes can protect the variable parties and regulate multifarious activities. Particularly, given the increasing number of startup companies that scrambled for the seat

5 See Adinda Normala, 'OJK Warns of New Cryptocurrency-Based Investment' (26 January 2018) Jakarta Globe.

6 The official full name is "Satuan Tugas Penanganan Dugaan Tindakan Melawan Hyukum Di Bidang Penghimpunan Dana Masyarakat dan Pengelolaan Investasi.”. 
in the new market laying for a chance of successful business and the large size of related criminal cases reported in other countries (e.g. hacking, embezzlement, etc.), urgency of the related studies cannot be stressed enough.

Against this backdrop, this research firstly examines what the virtual currency is under the current laws and regulations of Indonesia with the method of conceptual analysis. This will help clarify the legal status of a virtual currency and its holder, and how to protect the related parties using the existing laws and regulations. More importantly, this would show how BAPPEBTI Regulation No.5 of 2019 fails in successfully conceptualizing the subject matter.

Subsequently, this paper discusses more practical aspects by analyzing each activity of the business of its exchange. Even if a direct regulation is newly enacted, some of these activities will be still governed by the same laws and regulations. Lastly, the potential legal problems are selected by interviewing a practitioners and lawyers and subsequently the disastrous issues in the current BAPPEBTI regulation to resolve these problems are discussed.

\section{LEGAL MATERIALS AND METHOD}

It is a normative legal research using primary and secondary legal materials. While the primary legal materials consist of all the legal framework related to cryptocurrency both internationally and domestically, secondary ones included the references, including books, journal articles as well as conference papers and other documents

A similar approach is used globally. See Bae Seung Wook, A study on the Establishment of Virtual Currency Legal System, Foreign Language College of Korea, (PhD theses, 2018), 60-62; and having correlation with the issues. The technique of analysis data used legal interpretation.

Legal frameworks mentioned above include Indonesian Civil Code, Japanese Civil Code, South Korean Civil Code, New York Code Rules and Regulations and other legal documents related to cryptocurrency produced both by the governemnt and by national banking services.

\section{RESULTS AND DISCUSSIONS}

The Virtual Currency Under The Current Laws and Regulations of Indonesia : Is Virtual Currency A Personal Property Codified In The Book Two Of The Indonesian Civil Code?

\section{a. Premise}

The current legal definition of virtual currency is significantly misleading. To avoid misunderstanding, the original definition from the very creator as a chain of digital signature must be referred. 7 According to Art. 1 Para. 12 of No.11/2018 Electronic Information and Transactions Act, Electronic Signature means "a signature that contains Electronic Information that is attached to, associated or linked with other Electronic Information that is used for means of verification and authentication." Therefore, even taking into account the different aspect between "a chain of digital signatures" and an "electronic signature", it is still difficult to reject the nature as an electronic information composed of digitalized signatures in understanding the fundamental concept of virtual currency.

Lee Weon Sam, 'Understanding and Legal Status of Virtual Currency - Focusing on Bitoin, The Korea Commercial Cases Association', (2018) 31(2) Commercial Cases Review, 279-307. 
Under the assumption that virtual currency is electronic information made of digitalized signature, this paper goes over the analysis. This chapter has been discussed at the earlier research "Legal Status of Virtual Currency in Indonesia in the Absence of Specific Regulations" at Indonesia Law Review of University of Indonesia, ${ }^{8}$ and yet reviewed again by Indonesian lawyers at Dentons HPRP (Hanafiah Ponggawa \& Partners) for the purpose of this paper.

\section{b. The Nature as an Asset and Personal Property}

Despite the logical difficulty to recognize electronic information itself as a valuable personal property, it seems extremely difficult from a global perspective to deny the nature of virtual currency as an asset and property under either civil or criminal law based on its economic value widely recognized in the market without prohibition of trading.

The Amsterdam Court views that bitcoin as a personal property by stating " $[i] n$ the court's view, it thus shows characteristics of a property right." 9 As Indonesia still uses the Indonesian Civil Code adopted by the Netherlands in colonial period, the Dutch Court's decisions on the same provision may

8 Soonpeel Edgar Chang, Legal Status of Virtual Currency in Indonesia in the Absence of Specific Regulations, Indonesia Law Review, (2018) 3: 328-348.

9 "Naar het oordeel van de rechtbankvertoont het hiermeekenmerken van eenvermogensrecht." Rechtbank Amsterdam, ECLI:NL:RBAMS:2018:869. C/13/642655.

10 See Wilma Woo, Russia: Court Rules Bitcoin is Property in Landmark Bankruptcy Case (8 May 2018) Bitcoinist. <http://bitcoinist.com/russiancourt-rules-bitcoin-property/> accessed on 14 August 2018.

11 The indictment letter reads "Bit Coin is digital money or called gold of internet in the form of the same digital commodity wherever and can be used to transacted as an online shopping [.] Bit coin is give an influence over Indonesia's modern application of the same stipulation

In some of those civil-law jurisdictions having no specific regulations, the court came to the same or similar conclusion. Absent any particular regulation over Bitcoin, the Supreme Court in South Korea decides in 2018Do3619 that Bitcoin can be specified as an intangible property having a valuable asset and thus can be subject to seizure of hidden assets under the criminal procedures. Furthermore, Russia criminalizing Bitcoin as money substitute as Indonesia does recently classified cryptocurrency as property after a bankruptcy court forced a debtor to include his holdings in his personal wealth. ${ }^{10}$

Indonesian legal practice is not very different from this global trend. In a recent Indonesian criminal case (103/PID/2016/PT.DKI), the public prosecutor appears to recognize Bitcoin as a personal property in its indictment which the Court accepted. In the indictment, the public prosecutor regards Bitcoin as a separate form of commodity independent from an internet server that can be commercially transacted. ${ }^{11}$

Furthermore, the Ministry of Trade further explicitly announced that crypto currency is a crypto asset and commodities in the Regulation No.99/2018. Bappebti also declared that crypto currency is a commodity decentralized network that does not have server.
[And Bit coin] is automatically connected between
bitcoin software of whatsoever application which
is used by user, which is not in the form of
conventional currency in general, which has been
determined by central banks in all countries. (Bit
Coin adalah uang digital atau disebut emas
internet berupa komoditas digital yang sama di
mana pun dan dapat digunakan untukbertransaksi
belanja online, bit coin adalah jaringan
terdesentralisasi yang tidak memiliki server dan
saling terhubung secara otomatis antar software
bitcoin apapun aplikasinya yang digunakan oleh
pengguna, yang tidak secaranya tadalam bentuk
mata uang konvensional pada umumnya, yang
sudah ditentukan Bank Central di seluruh Negara)"

$\mathbf{8 0}$ | Chang - Legal Status of Cryptocurrency in Indonesia and Legal Analysis... 
in a digital asset field through Article 1 Paragraph $f$ Item 1 of the Regulation No.3/2019. Despite the controversial issue whether cryptocurrency satisfies the nature of "commodities" or "asset", the regulation made this point clear by explicitly determining it as an asset and commodity on its face.

Thus, albeit virtual currency is physically and scientifically a chain of digital signatures, the legal nature of virtual currency as an asset and personal property seems to be undeniable. It must be noted that this nature is recognized not because of its practical utility or the characteristics of electronic digital signatures but because of its economic nature -the demand and supply in the market- and the absence of contrary laws and regulations.

The issue is then how the existing Indonesian laws and regulations are applied to this new type of asset.

\section{c. Absence of Numerus Quasi-Clausus Theory in Indonesia}

12 Francesco Parisi, 'The Fall and Rise of Functional Property' (2005) November George Mason Law \& Economics Research Paper No. 05-38, 18.

13 For examples of current numerus clausus in civil law jurisdictions, Article 175 of Japan Civil Code (Establishment of Real Rights) "No real rights can be established other than those prescribed by laws including this Code."; Article 185 of South Korean Civil Code (Kinds of Real Rights) "No real right can be created at will other than ones provided for by law or customary law."; In German law the numerus clausus principle has a constitutional foundation and limits property rights in their number (Typenzwang) and content (Typenfixierung). Alexander Peukert, Goods allocation as a legal principle XXII, (Jus Privatum, 2008), p.138. This is not different in common law jurisdictions nowadays. "[t]he numerus clausus doctrine is characteristic of the post-feudal civil law systems. However, the feudal system still is the basis for property law in England and countries with property law systems which are historically based on English law such as the United States. It will, for that reason, come as no surprise that the numerus clausus doctrine, even the concept of numerus clausus as such, was hardly ever
"Numerus clausus" is a legal principle of property law which limits the number of types of rights that the courts will acknowledge as having the character of "property" and has its roots in Roman law. ${ }^{12}$ Nowadays, many countries either civil-law or common-law jurisdiction apply this principle. ${ }^{13}$

\section{Because Indonesian Civil Code} codified by the Dutch on 5 July 1830 and enacted in 1948 has its roots in Code Civil des Francais or Code Napoleon, which adopts the principle of numerus clausus in Article 544, ${ }^{14}$ the same principle should apply in Indonesia as both the Netherlands and France do. The main reference in Indonesian Civil Code in this line is Art. 499 stating "[t]he law interprets as assets all goods and rights which can be the subject of property."

To regulate new forms of rights in property that are not codified under civil codes, numerus quasi-clausus has been systematically accepted in a few civil-law

discussed in English and American legal literature. This seems to be changing. In 1993 Gordley pointed out that, at least from an American perspective, the conceptual differences between civil and common property law are no longer fundamental. In a very interesting, recent, exchange of views, Hansmann and Kraakman have debated with Merrill and Smith whether the numerus clausus doctrine also exists, albeit perhaps implicitly, in American property law. They all seem to agree that in American common law standardisation has taken place, which in its final result comes close to the civil law numerus clausus." Sjef van Erp, 'A Numerus Quasi-Clausus of Property Rights As A Constitutive Element of A Future European Property Law?' (2003) 7(2 June) Netherlands Comparative Law Association, Nedelandse Vereniging Voor Rechtsvergelijking.

14 See Dr. Irawan Soerdojo, S.H., M.Si, 'The Development of Indonesian Civil Law' (2016) 4(IX) Scientific Research Journal, 30; and Dhaniswara K. Harjono, 'Pengaruh Sistem Hukum Common Law Terhadap Hukum Investasi Dan Pembiayaan Di Indonesia', (2009) 6 (3) Lex Jurnalica , 180. 
states, ${ }^{15}$ and further asserted for more variable rights in a number of these jurisdictions including the Netherlands. ${ }^{16}$

In these countries, in an attempt to construe variable rights out of virtual currency which have never existed in history, some argue that digital information or a chain of digital information itself cannot constitute assets under the meaning of civil code because it is easily duplicated, copied, distributed and transmitted and thus cannot be deemed as independently existing, identifiable and controllable, all of them are elements of goods. Some of them further allege that although virtual currency cannot constitute a traditional asset under the civil code, the rights involved in virtual currency must be protected by widely applying the numerus clausus mutatis mutandis. ${ }^{17}$

Should the same logic be applicable in Indonesia, the Book Two of the Indonesian Civil Code would be applicable mutatis mutandis to the rights arising out of virtual currency. Unlike these countries, nonetheless, Indonesia appears to have barely developed the principle of numerus quasi-clausus. This is not surprising given the current level of legal researches and education in Indonesia lacking any referable collection of academic explications and theoretical development in Civil Code that must be full of rigor and originality from numerous passionate scholars.

\section{d. Direct Application of Numerus Clausus}

Against these backdrops, it seems much persuasive in Indonesia that the Book

15 For instance, in South Korea and Japan, Numerus Quasi-Clausus (Jun-mul-kwon in Korean and zyunbukken in Japanese) includes fishery right and mining right, both of them are not codified under numerus clausus in civil codes.

16 "I would argue that the strict civil law numerus clausus doctrine should not be applied as strictly as it is done in, e.g., the Netherlands. It should
Two of the Indonesian Civil Code directly covers virtual currency as intangible property. The referable articles in the Indonesian Civil Code are as follows:

Art. 500 "[a]nything that, due to a property right, comprises part of a property, including products, either produced naturally or through labor, to the extent that these are attached to the branch or roots, or attached to the soil, shall be deemed to comprise part of the assets."

Art. 503 "every property is tangible or intangible."

Art. 504 "every property is movable or immovable [...]."

While the form of intangible property is not specifically identified, the Indonesian Civil Code implicates that an intangible property is what could give the right to enjoy property or have economic value. Also, in the absence of direct laws and regulations, there is no prevailing reason to limit the direct application of the Book Two to only corporeal or material assets.

Art. 613 requires a record to show the ownership and/or transfer of the intangible property. Considering that virtual currency can be traded with the electronically recorded ownership, account and open records through the block chain technology, it satisfies Art. 613 as well.

\section{e. Consequences of Directly Applying The Book Two Of The Indonesian Civil Code}

1) Measure of Damages

82 | Chang - Legal Status of Cryptocurrency in Indonesia and Legal Analysis... 
If virtual currency is lost or broken, or not properly transacted (i.e., fraud, cybercrime, erroneous transaction, negligent management, etc.), measure of damages brings out great legal uncertainty and the victim must rely only on terms and conditions.

Because a virtual currency is not securities as explained later, the victim of fraud, cybercrime, erroneous transaction or negligent management cannot be protected under securities regulations to recover the arbitrage. In order to claim the largest damages, the claimant must be able to bring out the rules, relevant theories and cases applicable under the Book Two of Civil Code that the value of his personal property must be measured by (i) the market value at the time of lose; (ii) the historical value; or (iii) the higher of either (i) or (ii). For this purpose, the plaintiff could argue both breach of contract and tort.

On the contrary, the business holder of virtual currency exchange must be able to bring out defenses applicable under the Book Two of Civil Code because he is widely exposed to claims regarding a recovery of damages due to erroneous transactions or late measurements.

In some cases, the court may award damages which go beyond a strict measure of compensation. Example of noncompensatory damages include nominal damages, aggravated damages, restitutionary damages and account of profits. In Indonesia, this is left to the Judge to a great extent by the principle ex aquoet bono.

If the value of subject matter becomes an issue in Indonesian litigation, it generally needs public appraise or relevant authorities to measure the value. Nonetheless, at this point, one cannot determine the most appropriate institution for valuation of virtual currency.
2) The Statute of Limitation regarding Personal Property Claim

Art. 1967 of Indonesian Civil Code states "[a]ll legal claims, either property as well as individual in nature, expires after thirty years and the individual who invokes the expiration is not be required to submit any title, and an individual cannot object to this expiration if such is based upon bad faith."

3) Object of Collaterals or Impersonal Security

Although a personal property may be used as an object of collaterals or impersonal security by writing a contract between parties, using virtual currency as a collaterals or security brings great legal complexity regarding the precise secured value in virtual currency, tender of possession, foreclosure and execution procedures. That is thought to be beyond the purpose of exchange business. Because operators of virtual currency exchange regard the legal uncertainty as harmful to the business, some foreign exchange business holder use terms and conditions to forbid collateralizing the virtual currency traded in its exchange or exempt itself from any consequence of such collateral or security. In contrary, the terms and conditions which Indodax, the biggest player in Indonesian cryptocurrency market, use at this point does not stipulate in regard to the collaterals or security.

\section{4) Death of Virtual Currency Holder}

A personal property is subject to inheritance, which is notoriously complex in Indonesia. This complexity is partially because of Indonesia Civil Code which has never been amended since its codification in the beginning of 19th century and additionally because of mixed practice with Islam law conflicting with the relevant 
provisions in Civil Code. The details of this complexity are beyond the purpose of this paper and thus are not discussed.

\section{5) The Nature of Virtual Currency Exchange}

As explained later, Indonesian legal experts and financial supervisory service's opinions are gradually converging to the view that virtual currency is a part of fintech. If a virtual currency is indeed recognized as a property within fintech sector, virtual currency exchange could constitute an exchange of personal financial properties in the vacuum of a separate regulation. In Indonesia, there is no umbrella regulation to govern an exchange business of financial products yet.

\section{Is Virtual Currency A Contractual Right Under the Book Three Of The Indonesian Civil Code?}

Digital information itself does not constitute a contract and virtual currency is merely an object of mining, purchase and transfer (Official Elucidation of Art. 34 Item (a) of BI Reg. 18/69/PBi/2016). However, it can be subject to a contract in as much as not used as a payment measure or for criminal activities.

Although not stated among the examples in BI Reg. 18/69/PBI/2016 and BI Reg.19/12/PBI/2017, Ethereum is widely exchanged as one of the virtual currencies at Indonesian virtual currency exchange, Indodax. It is also globally known as having a nature of so-called "smart contract". The smart contract in this context means an encoding function or a computerized protocol that executes designated terms. Nonetheless, the smart contract is not a

18 See Sri Rahayu above n 3; and Dita Safitri, Bappebti Segera Rilis Aturan Aset Digital (29 April 2018) Dunia Fintech "contract" under the meaning of law. A contract arises from an agreement, or by law (Art. 1233 of Civil Code) not by encoding function or a computerized protocol.

\section{Is Virtual Currency An Copyrighted Property?}

The creators of virtual currency have opened it to the global public for free without registration of intellectual rights. Some of them have not even revealed their identity at all. Therefore, it is difficult for Indonesian regime to see it as copyrighted work as far as the creators do not register them as an industrial properties.

\section{Is Virtual Currency A Financial Property?}

\section{a. Is Virtual Currency A Property in Fintech Industry?}

Financial Technology or Fintech is "the utilization of technology in financial systems which delivers products, services, technology, and/or a new business model and also has an impact on monetary stability, financial system stability, and/or the efficiency, continuity, security, and reliability of the payment system." (Art.1 Para.1 of BI Reg. No.19/12/PBI/2017) Therefore, once a certain product or business is recognized under fintech industry, it is automatically viewed as a part of financial product or business.

For now, in the absence of any explicit stipulation whether virtual currency exchange is categorized under a financial business or not, Indonesian lawyers, news media and government officials nevertheless officially state that virtual currency business is one of Fintech area. ${ }^{18}$

Certainly, the definition of fintech implicates the possibility to include virtual

<https://www.duniafintech.com/bappebti-rilisaturan-aset-digital/> accessed on 14 August 2018.

84 | Chang - Legal Status of Cryptocurrency in Indonesia and Legal Analysis... 
currency exchange. Furthermore, Indonesia's official categories of fintech includes "other financial services" that can meet any of the followings "(i) innovation; (ii) ability to have an impact on products, services, technology, and/or on the existing financial business model; (iii) ability to provide benefits for society; (iv) ability to be widely used; and (v) other criteria mandated by Bank of Indonesia." (BI Reg. No.19/12/PBI/2017 concerning Implementation of Fintech) That is, there is no bright-line rule to exclude virtual currency from fintech area.

Naturally, as discussed earlier, virtual currency is likely to be construed as intangible assets under the Book Two of the Indonesian Civil Code and likely to constitute a financial product given the government's current stance. As a consequence, the exchange business is subject to the regulatory compliance issued and supervised by OJK and Bank Indonesia including financial consumer protection, privacy and data protection, anti-money laundering and counter-terrorist financing, know your customer rule, prudential banking, etc. Indeed, OJK made an Investment Watch Task Force to this end which specifically supervises and monitors any investment which has suspicious activities including the cryptocurrency trading sector. ${ }^{19}$

The more conclusive legal consequences depend on what type of

19 OJK, Press Release: Investment Alert Task Force Suspends 14 Business Activities to Protect Public (23 Oct 2017) <https://www.ojk.go.id/en/beritadan-kegiatan/siaran-pers/Pages/Press-ReleaseInvestment-Alert-Task-Force-Suspends-14Business-Activities-to-Protect-Public.aspx> assessed on 7 August 2018.

20 Securities means promissory notes, commercial paper, shares, bonds, evidence of indebtedness, Participation Units of collective investment contracts, futures contracts related to Securities, and all derivatives of Securities Art.1 Para.5 of the Act No.8/1995. financial product it is. The detailed are discussed below.

\section{b. Is Virtual Currency Securities?}

Virtual currency does not constitute a securities under Art.1 Para.5 of No.8/1995 Capital Markets Act and its official elucidation. ${ }^{20}$

Either virtual currency is a securities or not, some foreign jurisdictions such as United States, United Kingdom and Switzerland apply securities regulations to initial coin offering. ${ }^{21}$ Initial coin offering or ICO (also purported as token sale, initial token offering, ITO, or crowd sale) offers existing virtual currency, newly developing virtual currency, or token of certain rights involved in the project in order to solicit funds from the general public. The details about ICO are discussed at later part of this paper.

Some jurisdictions such as South Korea and China explicitly prohibits ICO as of now. The Indonesian regulatory regime does not explicitly prohibits ICO as they do. The widely-accepted legal opinion in Indonesian market so far seems to be that Indonesia makes it virtually impossible to carry out ICO by banning the use of virtual currencies as payment instruments. (Article 8 of BI Reg.19/12/PBI/2017). ${ }^{22}$

Therefore, those regulations concerning securities or capital market do not

21 United States (SEC, "Release No.81207; Report of Investigation Pursuant to Section 21(a) of the Securities Exchange Act of 1934: The DAO”, July 25, 2017); Switzerland (FINMA, "Regulatory treatment of initial coin offerings", FINMA Guidance 04/2017, 2017.9.29), and United Kingdom (FCA, "Initial Coin Offerings", Statements, 2017.9.12.

22 "Similar to a virtual currency, the ICO is not yet specifically regulated under the prevailing laws and regulations in Indonesia. At this stage, a definition of or coverage of an ICO is also not available under this existing regulations...... Taking a conservative approach, it would not 
govern virtual currency or its exchange business.

\section{c. Is Virtual Currency A Future Commodity?}

In earlier days, it was not legally impossible to view some types of cryptocurrency as a "Future Commodity" under Indonesian Future Commodity Act, ${ }^{23}$ because trading certain types of cryptocurrency (e.g., Bitcoin) practically required an unguaranteed time gap an order and encashment. Nevertheless, this is no longer the case nowadays. The recent types of virtual currencies such as Ripple allow prompted and real-time sales. In other words, defining all the virtual currencies as commodities in future market is legally incorrect. Furthermore, trading cryptocurrency in one exchange does not necessitate a time interval as a future market does.

This triggers a constitutional problem in the recent enactment of BAPPEBTI Regulation. This problem is discussed in a separate chapter.

\section{d. Is Virtual Currency a Currency?}

As discussed earlier, virtual currency cannot be used a currency in Indonesia. Notwithstanding its definition as digital "money", it is not legally recognized as a

appear that an ICO can be deemed a public offering under Indonesian law." Fahrul S Yusuf and Harry Kuswara, 'Weighing the future', (16 July 2018) International Financial Law Review.

23 "A Commodity means any goods, service, right or other interest... subject of a Future Contract [...]" and "Future Contract means a form of standard contract for a sale or purchase of a Commodity with a future settlement stipulated in the contract, which is tradable on the Futures Market." Art.1 Para. 2 and 5 of Law No.19/2011 (amendment of Law No.32/1997 concerning Future Commodity).

24 BI Reg. No. 18/40/PBI/2016 concerning the Implementation of Payment Transaction Processing. valid payment instrument in Indonesia (Article 8 of BI Reg.19/12/PBI/2017). Nor is it recognized as a legal currency despite its name of virtual "currency" because Rupiah is the only national currency in Indonesia (BI Reg. No.7/2011).

\section{e. Is Virtual Currency Electronic Money?}

Electronic money or E-money is used for payment system and governed by a separate regulation. ${ }^{24}$ The business holder of E-money is required to have a Payment System License as electronic money operators issued by Bank Indonesia. ${ }^{25}$ In contrary, virtual currency cannot be used for payment system.

\section{f. Is Virtual Currency A New Type Of Financial Property?}

As seen in the above discussion, virtual currency does not suitably belong to any existing financial product while the Indonesian government officials mention it as a financial technology and the Indonesia criminal court recognizes it as a property. Thus, it must constitute a new financial property that can be commercially used or transacted as far as it is not used as payment method and the way of use does not violate laws and regulations. The OJK expressed the same opinion. ${ }^{26}$

25 There are 29 license holders as of July 27th 2018. See Bank Indonesia, List of Electronic Money Operators Licensed by Bank Indonesia Bank and Non Bank Institutions, (27 July 2018) $<$ https://www.bi.go.id/en/sistempembayaran/informasi-perizinan/uangelektronik/penyelenggara-

berizin/Pages/default.aspx $>$ accessed on 14 August 2018.

26 "Sampai sekarang belum ada yang cocok 'dudukannya'. Ini asset baru dunia digital. Disebut komoditas mereka ngga cocok, Bitcoin ini aset digital yang ada di server. Apakah ini uang? Tidak. Ketiga, apakahproduk yang ada di area investasi? Kami tanyake expert, underlying tidakada. Jadi, susah memasuk anke dalam tiga 


\section{Flaws in Recent Regulation of Indonesia}

a. Cryptocurrency Regulations od Other Countries

Before discussing the problems in the recent Indonesian regulation over the virtual currency, the global trend in making laws and regulations over the same subject matter must be examined to maintain a balanced view. In 2018, the Library Congress, the largest library in the worlds and the main research arm of the U.S. Congress and the home of the U.S. Copyright Office, reported its survey of the legal and policy landscape surrounding cryptocurrencies around the world covering 130 countries and some regional organizations that have issued laws or policies on the subject. ${ }^{27}$

According to this research, one of the most common actions identified across the surveyed jurisdictions is government-issued notices about the pitfalls of investing in the cryptocurrency markets. Such warnings, mostly issued by central banks, are largely designed to educate the citizenry about the difference between actual currencies, which are issued and guaranteed by the state, and cryptocurrencies, which are not. Most government warnings note the added risk resulting from the high volatility associated with cryptocurrencies and the fact that many of the organizations that facilitate such transactions are unregulated. Most also note that citizens who invest in cryptocurrencies do so at their own personal risk and that no legal recourse is available to them in the event of loss.

Many of the warnings issued by various countries also note the opportunities

jenis tadi," Said Fithri Hadi Direktur Inovasi Keuangan Digital OJK. See Nanda Narendra Putra, Risiko Jual-Beli Bitcoin Tidak Dijamin Otoritas Manapun, (13 Jan 2018) Hukum Online.

27 The Law Library of Congress, Global Legal Research Center, Regulation of Cryptocurrency that cryptocurrencies create for illegal activities, such as money laundering and terrorism. Some of the countries surveyed go beyond simply warning the public and have expanded their laws on money laundering, counterterrorism, and organized crimes to include cryptocurrency markets, and require banks and other financial institutions that facilitate such markets to conduct all the due diligence requirements imposed under such laws. For instance, Australia, Canada, and the Isle of Man recently enacted laws to bring cryptocurrency transactions and institutions that facilitate them under the ambit of money laundering and counter-terrorist financing laws. Bank Indonesia statement on January 13, 2018, Bank Indonesia Regulation No.18/40/PBI/2016 on Implementation of Payment Transaction Processing and Bank Indonesia Regulation No. 19/12/PBI/2017 on Implementation of Financial Technology are also covered in this line. ${ }^{28}$

Some jurisdictions have gone even further and imposed restrictions on investments in cryptocurrencies, the extent of which varies from one jurisdiction to another. Some (Algeria, Bolivia, Morocco, Nepal, Pakistan, and Vietnam) ban any and all activities involving cryptocurrencies. Qatar and Bahrain have a slightly different approach in that they bar their citizens from engaging in any kind of activities involving cryptocurrencies locally, but allow citizens to do so outside their borders. There are also countries that, while not banning their citizens from investing in cryptocurrencies, impose indirect restrictions by barring financial institutions within their borders

Around the World, June 2018. < https://www.loc.gov/law/help/cryptocurrency/wor ld-survey.php>

28 Ibid, 109-110. 
from facilitating transactions involving cryptocurrencies (Bangladesh, Iran, Thailand, Lithuania, Lesotho, China, and Colombia).

Not all countries see the advent of blockchain technology and cryptocurrencies as a threat, albeit for different reasons. Some of the jurisdiction, while not recognizing cryptocurrencies as legal tender, see a potential in the technology behind it and are developing a cryptocurrency-friendly regulatory regime as a means to attract investment in technology companies that excel in this sector. In this class are countries like Spain, Belarus, the Cayman Islands, and Luxemburg.

Some jurisdictions are seeking to go even further and develop their own system of cryptocurrencies. This category includes a diverse list of countries, such as the Marshall Islands, Venezuela, the Eastern Caribbean Central Bank (ECCB) member states, and Lithuania. In addition, some countries that have issued warnings to the public about the pitfalls of investments in cryptocurrencies have also determined that the size of the cryptocurrency market is too small to be cause for sufficient concern to warrant regulation and/or a ban at this juncture (Belgium, South Africa, and the United Kingdom).

One of the many questions that arise from allowing investments in and the use of cryptocurrencies is the issue of taxation. In this regard the challenge appears to be how to categorize cryptocurrencies and the specific activities involving them for purposes of taxation. This matters primarily because whether gains made from mining or selling cryptocurrencies are categorized as income or capital gains invariably determines the applicable tax bracket.

29 Peraturan Menteri Perdagangan No.99/2018 tentang Kebijakan Umum Penyelenggaraan Perdagangan Berjangka Aset Kripto
Despite the global tendency of skepticism, no jurisdiction surveyed in this report defines the cryptocurrency service or business as future trading industry.

\section{b. Ministry of Trade Regulation No. 99 of 2018}

After Bappebti announced its plan to adopt a new regulation to govern cryptocurrency transactions in 2018, the Ministry of Trade introduced the regulation No.99/2018 on 20 September 2018 to permit a trade of Crypto Asset. ${ }^{29}$ This short regulation has only the three articles: (1) Crypto Asset is designated as a commodity which can be a subject of future contract traded at the Future Exchange (emphasis added); (2) Any further regulation, guidance, supervision and development regarding the establishment of Crypto Assets as a commodity that can be the subject of Future Contract traded at the Future Exchange shall be determined by the Head of the Trade Supervisory Board of the Future Commodity; and (3) This Ministry Regulation is valid from the signing date.

As discussed earlier, cryptocurrency does not constitute a future commodity, either legal or physical nature. The recent types of virtual currencies such as Ripple allow prompted and real-time sales. Besides, trading cryptocurrency in one exchange does not necessitate a time interval as a future market does. In other words, either crypto asset, cryptocurrency, digital currency or whatever name we coin, defining all the related business as a future business would be significantly misleading.

Thus, the regulation No.99/2018 must be thought to regulate only where virtual currency is traded as future products, rather 
than to view the exchange of virtual currency itself as a future trading. In other words, the regulation No.99/2018 would be legitimate and lawful only where this interpretation is applied.

\section{c. Bappebti Regulation No.5 of 2019}

1) Theoretical Problem: Incorrect Authority Bappebti recently issued the Regulation of Supervisor Agency of Future Commodity Trading No. 5 of 2019 concerning Technical Provision for Performing the Physical Market of Crypto Asset in Futures Exchanges. BAPPEBTI Regulation No.5 of 2019 is different with Ministry of Trade Regulation No.99 of 2018 in that it clearly aims to govern the whole business service and entities of cryptocurrency by specifying crypto asset service (Article 1 Paragraph 9) and clearing (Article 1 Paragraph 5).

Nonetheless, virtual currency exchange is not a future trade in its nature as discussed earlier. Figuratively speaking, rice or pineapple may be traded through a forward agreement but purchasing rice or pineapple at convenient store is not a forward trade. Similarly, virtually currency can be traded through a future agreement but purchasing a virtual asset is not a future agreement. Indeed, Article 1 of the Ministry of Trade Regulation No.99/2018 does not define Crypto Asset as a future commodity but "a commodity can be a subject of future contract (Komodity yang dapat dijadikan Subjek Kontrak Berjangka yang diperdagangkan di Bursa Berjangka)."

According to Art 1. Para. 4 of Commodity Futures Trading Act No.32/1997 amended by Act No.10/2011) defines the futures contract as "a standardized contract form to purchase or sell Commodities in quantity, quality, time, place and type of submission at a later date that has been set, and includes in the notion of the contract."
Trading cryptocurrency in one exchange does not necessitate a time interval as a future market does. Further, a number of cryptocurrencies do not necessitate time interval for trade at all.

Naturally, there is a constitutional question on the BAPPEBTI Regulation No.5 of 2019 which has been issued under the assumption that Bappebti has the due authority to govern the business of cryptocurrency exchange. That is, due authority of relevant field is a constitutional question based on Article 17 Paragraph (3) and Article 18A (1) of Indonesian Constitution. An irrelevant legislation without due authority can nullify the entire regulation. And that would be disastrous to the market participants as it already is to the Indonesia's legal system and legal certainty.

\section{2) Practical Problem: a Lack of Protection for Bona Fide Participants}

According to BAPPEBTI Regulation No.5 of 2019, futures exchanges and clearing houses dealing with crypto assets must have paid-up capital of at least 1.5 trillion Indonesian rupiah (USD 106 million) and must maintain a closing capital balance of at least 1.2 trillion Indonesian rupiah (USD 85 million). Further, traders of crypto assets must maintain minimum paid-up capital of 1 trillion Indonesian rupiahs (USD 71 million) and a minimum closing balance of 800 billion Indonesian rupiah (USD 57 million). This unrealistic figures out of nowhere drew harsh criticism from the market and critics since even the largest exchange of the 
country cannot follow the regulation. ${ }^{3031}$ To the market participant's view, BAPPEBTI Regulation No.5 of 2019 seems simply way out of bounds. ${ }^{32}$.

Following the announcement of the regulation, Bappebti invited some cryptocurrency exchange business holders within Indonesian Blockchain Association to the meeting on 19 February 2019 and suggested two options for votes: ${ }^{33}$ (i) working capital to be fixed to $80 \%$ of paid-up capital; or (ii) working capital to comply with a debt to equity ratio of 1:2. Because this suggestion is too rough to address the issues potentially making other loopholes, the discussion is still ongoing amongst the market participants and Bappebti.

Unfortunately, BAPPEBTI Regulation No.5 of 2019 does not have any enabling clause to protect market participants. In other words, the Indonesia's regulation merely restrict the business of cryptocurrency exchange and services without protection of regular users who already put their money into the market. A legal authority must understand that any sudden prohibition of financial market can lead to frightening consequences to bona fide participants in the market, particularly where they could not see it coming.

As mentioned in the earlier study, ${ }^{34}$ regular crypto-asset service users are exposed to certain risks including malware, hacking, malfunction, congestion,

30 Krystle M, New Crypto Futures Rules by Indonesia's BAPPEBTI Poorly Received by Traders (Bitcoin Exchange Guide, February 14, 2019)

31 Indrasari Wisnu Wardhan, Head of BAPPEBTI, is already aware of this problem according to the speech in the meeting with Indonesian Blockchain Association.

32 Krystle M, above n 30.

33 Attendees: BAPPEBTI, Indonesian Blockchain Association, Indodax, Luno, Coinone, Triv, embezzlement, etc. Some of these problems are caused by the user's own negligence (e.g., leaving public computers without logging out, leaking his/her pin codes, etc.) or willful conducts (e.g., joint offender of hacking). Not to mention, in some cases, the cryptocurrency exchange cannot have a control over each of individual customers' node and each customer has the better position to protect him/herself from session hijacking ${ }^{35}$ or spoofing. ${ }^{36}$ However, that does not mean that the governmental policy and regulations can simply leave these risks or burdens to the general public. They must be protected.

\section{CONCLUSIONS AND SUGGESTIONS}

There is no such thing as a legal vacuum or a regulation-free zone, as some defenders of virtual currency might want to think. Certainly, Indonesia's recent development in legal policy toward cryptocurrency is pertinent to ask whether this new investment market has any more risk to throw over Indonesia than how to protect the existing variable parties by overall structural formation. This study contend that any effective implementation of this new ecosystem requires the machinery of more fundamental concepts and keynote of policy acceptable to Indonesia for the protection of related parties. Nonetheless, most importantly, BAPPEBTI Regulation No. 5 of

Bitocto, Bido, Udax, Pintu, Digital Exchange, KoinX, Rekeningku, Tokocrypto and Nuchex.

34 Soonpeel Edgar Chang, above n. 8, 343.

35 In computer science, session hijacking, also known as cookie hijacking, means the exploitation of a valid computer session to gain unauthorized access to information such as ID and password.

36 In the context of network security, a spoofing attack is a situation in which a person or program successfully masquerades as another by falsifying data, to gain personal information such as ID or Email address. 
2019 cannot be the good answer to this challenge and will only harm bona fide market participants without a good-standing authority.

Of course, there are a number of challenges when it comes to enacting a direct regulation. It is first necessary to characterize virtual currency in order to apply a set of predetermined rules; that is already challenging enough given the diverging voices and visions toward the future of cryptocurrency over the world. Even if the legal concept and regulatory frame is structured, the execution and enforcement would be challenging: once the relevant rules are determined, the conflict of laws and jurisdictions question kicks in. ${ }^{37}$ These challenges must be promptly overcome under the clear direction of national policy.

\section{REFFERENCES}

\section{Books}

Chang, Soonpeel Edgar, Indonesian Company Law (Routledge, 2018)

Chang, Soonpeel Edgar, 'Legal Status of Virtual Currency in Indonesia in the Absence of Specific Regulations' (2013) 3 Indonesia Law Review.

Peukert, Alexander, Goods allocation as a legal principle XXII, (Jus Privatum, 2008)

\section{Journals Articles}

Barsan, Iris, 'Legal Challenges of Initial Coin Offerings (ICO)' (2017) 3 Revue Trimestrielle de Droit Financier (RTDF).

Harjono, Dhaniswara K., 'Pengaruh Sistem Hukum Common Law Terhadap Hukum Investasi Dan Pembiayaan Di Indonesia' (2009) 6(3, Agustus) Lex Jurnalica, 180.
M., Krystle, New Crypto Futures Rules by Indonesia's BAPPEBTI Poorly Received by Traders (Bitcoin Exchange Guide, February 14, 2019)

Parisi, Francesco, 'The Fall and Rise of Functional Property' (2005) November George Mason Law \& Economics Research Paper No. 05-38.

Sam, Lee Weon, 'Understanding and Legal Status of Virtual Currency - Focusing on Bitoin', (2018) 31(2) The Korea Commercial Cases Association, Commercial Cases Review.

Sjef van Erp, 'A Numerus Quasi-Clausus of Property Rights As A Constitutive Element of A Future European Property Law?' (2003) 7(2, June) Netherlands Comparative Law Association, Nedelandse Vereniging Voor Rechtsvergelijking.

Soerdojo SH., MSI, Dr. Irawan, 'The Development of Indonesian Civil Law' (2016) IV(Issue IX. September), Scientific Research Journal.

Wook, Bae Seung, 'A study on the Establishment of Virtual Currency Legal System' (2018) Foreign Language College of Korea, Doctorate theses.

Yusuf, Fahrul $S$ and Harry Kuswara, 'Weighing the future' (2018) International Financial Law Review, 16 July 2018.

\section{Legislations and other Legal Document}

Indonesian Civil Code

Japanese Civil Code

South Korean Civil Code

Bappebti Regulation No. 2 of 2016

Bank Indonesia Regulation. No. 18/40/PBI/2016 concerning the

37 See Iris Barsan, above n. 35, 54-65. 
Implementation of Payment

Transaction Processing

Bank Indonesia Regulation.

No.19/10/PBI/2017 Fithri Hadi

Direktur Inovasi Keuangan Digital OJK.

Communication Department of Bank Indonesia, Bank Indonesia Warns All Parties Not to Sell, Buy, or Trade Virtual Currency, 13 January 2018.

FCA, "Initial Coin Offerings", United Kingdom FCA Statements, 12 September 2017.

Financial Crimes Enforcement Network, “Application of Fin CEN's Regulations to Persons Administering, Exchanging or Using Virtual Currencies," FIN2013-G001, 18 March 2013.

Financial Action Task Force, "Virtual Currencies - Key Definitions and Potential AML/ CFT Risks", Financial Action Task Force Report, 2014. 6.

FINMA, "Regulatory treatment of initial coin offerings", FINMA Guidance 04/2017, 2017.9.29),

Indonesian Ministry of Finance, Warning Against the Use of Virtual Currency in Indonesia, 22 January 2018.

New York Code Rules and Regulations, Title. 23 sec. 200.4 200.20.

President Regulation No.13 of 2018 on the Implementation of the Principle of Knowing Beneficial Owners of Corporation in Relation to the Prevention and Eradication of Money Laundering and Terrorism Financing Crimes

Regulation of the Conduct of Virtual Currency Business, 37 N.Y. Reg., June 24, 2015, Art. 200.2(p).

Regulation of the Indonesian Ministry of Trade No.99/2018 concerning Future Trade of Crypto Asset.
SEC, "Release No.81207; Report of Investigation Pursuant to Section 21(a) of the Securities Exchange Act of 1934: The DAO”, July 25, 2017.

Pusat Pelaporan dan Analisis Transaksi Keuangan, Beware of the Use of Virtual Currency, 12 February 2018.

OJK, Press Release: Investment Alert Task Force Suspends 14 Business Activities to Protect Public, 23 Oct 2017. https://www.ojk.go.id/en/berita-dankegiatan/siaran-pers/Pages/PressRelease-Investment-Alert-Task-ForceSuspends-14-Business-Activities-toProtect-Public.aspx assessed on 7 August 2018

OJK Regulation No.77/POJK.01/2016 concerning P2P Lending

Law No.19/2011 concerning Commodity Futures Trade (amendment of Law No.32/1997 concerning Future Commodity).

Rechtbank Amsterdam,

ECLI:NL:RBAMS:2018:869.

C/13/642655.

\section{Internet Sources}

Dwivedi, Shubham, South East Asia: The State of Crypto and ICO regulation (23 June 2018) Koinalert. $<$ https://www.koinalert.com/southeast-asia-the-state-of-crypto-and-icoregulation/> assessed on 13 August 2018

Kim, Dahee, South Korean cryptocurrency executives detained over alleged embezzlement (5 April 2018) Thomson Reuters $<$ https://www.reuters.com/article/uscrypto-currencies-southkoreaarrests/south-korean-cryptocurrencyexecutives-detained-over-allegedembezzlement-idUSKCN1HC07D> accessed on 14 August 2018.

92 | Chang - Legal Status of Cryptocurrency in Indonesia and Legal Analysis... 
M, Krystle, New Crypto Futures Rules by Indonesia's BAPPEBTI Poorly Received by Traders (February 14, 2019) Bitcoin Exchange Guide

Memoria, Francisco, TRON Enters Indonesia as Local Exchange Indodax Adds TRX/IDR Trading Pair (3 June 2018) Cryptoglobe,

<https://www.cryptoglobe.com/latest/ 2018/06/tron-enters-indonesia-aslocal-crypto-exchange-indodax-addstrx-idr-trading-pair/> assessed on 13 August 2018.

Nakamoto, Satoshi, Bitcoin: A Peer-to-Peer Electronic Cash System (2008) $\langle$ www.bitcoin.org $>$

Normala, Adinda, OJK Warns of New Cryptocurrency-Based Investment (26 January 2018) Jakarta Globe.

Putra, Nanda Narendra, Risiko Jual-Beli Bitcoin Tidak Dijamin Otoritas Manapun (13 Jan 2018) Hukum Online.

Rahayu, Sri and Indriana Pramestri, Fintech 2018 Indonesia, (21 May 2018) International Comparative Legal Guides, <https://iclg.com/practiceareas/fintech-laws-and-

regulations/indonesia> assessed on 10 August 2018.

Rana, Aakanksha, Dash, NEM [XEM], Dogecoin [DOGE], and Bitshares [BTS] now available on Indodax, (25 July 2018) AMBCrypto, $<$ https://ambcrypto.com/dashnemxem-dogecoin-doge-and-bitsharedbts-now-available-on-indodax-fortrading/> assessed on 7 August 2018.

Safitri, Dita, Bappebti Segera Rilis Aturan Aset Digital (29 April 2018) Dunia Fintech

$<$ https://www.duniafintech.com/bappe bti-rilis-aturan-aset-digital/> accessed on 14 August 2018
Woo, Wilma, Russia: Court Rules Bitcoin is Property in Landmark Bankruptcy Case (8 May 2018) Bitcoinist. $<$ http://bitcoinist.com/russian-courtrules-bitcoin-property/> accessed on 14 August 2018. 